\title{
URBAN AND REGIONAL DEVELOPMENT PLANNING
}

Policy and Administration 
Digitized by the Internet Archive in 2012 


\title{
URBAN AND REGIONAL DEVELOPMENT PLANNING
}

Policy and Administration

\author{
DENNIS A. RONDINELLI
}

Cornell University Press | iтhaca and london 
Copyright (c) 1970, 1975 by Cornell University

All rights reserved. Except for brief quotations in a review, this book, or parts thereof, must not be reproduced in any form without permission in writing from the publisher. For information address Cornell University Press, 124 Roberts Place, Ithaca, New York 14850.

First published 1975 by Cornell University Press.

Published in the United Kingdom by Cornell University Press Ltd., 2-4 Brook Street, London W1Y 1AA.

International Standard Book Number 0-8014-0873-3 Library of Congress Catalog Card Number 74-18539

Printed in the United States of America by York Composition Co., Inc. 